\title{
Land-Use Changes Associated with Oil Palm Plantations Impact PLFA Microbial Phenotypic Community Structure throughout the Depth of Tropical Peats
}

\author{
Selvakumar Dhandapani ${ }^{1,2,3,4,5}$ (1) Karl Ritz $^{1} \cdot$ Stephanie Evers ${ }^{3,4,6} \cdot$ Hannah Cooper $^{1,6} \cdot$ Amanda Tonks $^{1,6}$. \\ Sofie Sjögersten ${ }^{1}$
}

Received: 4 June 2019 / Accepted: 15 July 2020 / Published online: 11 August 2020

(C) The Author(s) 2020

\begin{abstract}
Tropical peatlands are complex and globally-important ecosystems that are increasingly threatened by anthropogenic disturbances, primarily via agricultural development. Microbes in peatlands play important roles in governing overall ecosystem functions and sustenance, with specific population dynamics governing carbon sink or source dynamics. We determined phenotypic microbial community structures under forest, drained, burned and oil palm plantation peatlands, using phospholipid fatty acid (PLFA) profiling. Communities were distinct under each land-use type, varied consistently with depth down to two metres, but with a distinct characteristic shift at circa one metre depth. There was bacterial dominance across all land-use types and depths. The burnt peatland showed the greatest contrast relative to forest, possibly due to the difference in water table level. Gram-positive bacteria was the most dominant group in surface layers under all land-use types except burnt, and their relative abundance decreased with depth, replaced by Gram-negative groups in deeper layers. Fungal relative abundance remained low across both land-use types and depth ranges. Our results shed light on a hitherto virtually unknown tropical peat microbial phenotypic community structure and indicate that anthropogenic disturbance in tropical peatlands severely alter microbial communities.
\end{abstract}

Keywords Burnt and drained peatlands $\cdot$ Land use change $\cdot$ Microbial community structure $\cdot$ Oil palm plantations $\cdot$ Tropical peatlands

Electronic supplementary material The online version of this article (https://doi.org/10.1007/s13157-020-01342-0) contains supplementary material, which is available to authorized users.

Selvakumar Dhandapani

sccalva@gmail.com

1 School of Biosciences, University of Nottingham, Sutton Bonington, UK

2 Crops For the Future, Semenyih, Malaysia

3 Tropical Catchment Research Initiative (TROCARI), Kuala Lumpur, Malaysia

4 School of Biological and Environmental Sciences, Liverpool John Moores University, Liverpool, UK

5 Centre for Agri-Environmental Research (CAER), University of Reading, Reading RG6 6AH, UK

6 School of Biosciences, University of Nottingham Malaysia Campus, Semenyih, Malaysia

\section{Introduction}

Tropical peatlands are complex and globally-important ecosystems supporting distinctive biodiversity and high carbon (C) storage capacity, related to their unique acidic, nutrientpoor and waterlogged environmental conditions (Parish et al. 2008; Miettinen et al. 2012). Microbes in peatlands play important roles not only in the formation of peat itself, but also directly influence ecosystem $\mathrm{C}$ turnover and nutrient mineralization required to support primary production, affecting overall ecosystem function and sustainability (Andersen et al. 2013). Different anthropogenic disturbances impact contrasting environmental and biological factors, affecting the overall balance of peatlands, and can turn the peatlands from $\mathrm{C}$ sinks to C sources (Page and Hooijer 2016; Hapsari et al. 2017)..

Oil palm expansion is one of the most extensive and everincreasing anthropogenic disturbances faced by tropical peatlands in South East Asia (Miettinen et al. 2012; Rashid et al. 2013). During the conversion, forest land is usually 
completely cleared of vegetation to establish plantations (Bruhl and Eltz 2010; Luskin and Potts 2011). Oil palm plantations are generally maintained with regular harvesting, pruning, fertilization and pest management, causing significant changes to the environment and microclimate (Chung et al. 2000; Azhar et al. 2011; Luskin and Potts 2011). Observations from various studies in mineral soil systems show that oil palm plantations have relatively high soil and air temperature (Turner and Foster 2009; Lucey and Hill 2012), lower humidity (Turner et al. 2008; Gillespie et al. 2012), low pH similar to tropical forest (Chung et al. 2000) and very high temporal variation of such environmental characteristics (Gillespie et al. 2012; Lucey and Hill 2012). Documented environmental changes in tropical peatlands are limited and these studies showed similar patterns as seen in mineral soil (Tonks et al. 2017; Cooper et al. 2019; Dhandapani et al. 2019b, c). Though most mature oil palm plantations have a closed canopy (Peh et al. 2006), such canopies are typically homogenous and single-layered. This is unlike the multi-layered heterogeneous canopy structure characteristic of old-growth forests, which underpin a stable and moderate microclimate that provides a more appropriate habitat to provision understorey biodiversity. Another common feature is the high degree of soil disturbance arising from human movement and interference, and a complete lack of leaf-litter input in oil palm plantations (Peh et al. 2006; Cusack 2011).

Drained and burnt peatlands in South East Asia are either a pathway or by-product of oil palm expansion or logging (Bruhl and Eltz 2010). By 2015, 50\% of the peatlands in Malaysia, Borneo and Sumatra were managed for agricultural plantations, and only $29 \%$ remain forested, of which most are selectively logged, with only $6 \%$ of the peat swamp forests in the region have no sign of disturbance since 1990 (Miettinen et al. 2016). The drainage of peatland reduces the level of the water table, consequently exposing the organic peat to aerobic decomposition mediated via microbes. The lowering of the water table can directly impact soil temperature, aeration, pH, and salinity (Coyne 1999; Turetsky et al. 2015). Responses to environmental change is typically more rapid for soil microbes than other flora and fauna because of their short generation times and higher population numbers (Andersen et al. 2013). It is widely demonstrated that soil microbes respond to environmental changes induced by anthropogenic land use changes (Bossio et al. 2005; Hartman et al. 2008; Kerfahi et al. 2014; Krashevska et al. 2015; Wood et al. 2017). A general inference from the observed pattern of the microbial responses is that soil chemical properties, especially $\mathrm{pH}$, plays a key role in governing bacterial community structure (Hartman et al. 2008; Wood et al. 2017) while fungal community changes are more dependent on soil moisture level, $\mathrm{C}$ quality and composition (Thormann et al. 2004; Trinder et al. 2008, 2009; Asemaninejad et al. 2017).
Microbes in northern peatlands were found to vary with depth and be vertically stratified because of energy constraints such as organic matter quality, nutrient and oxygen availability, which become further influenced by disturbances (Sundh et al. 1997; Dedysh et al. 2006; Morales et al. 2006; Andersen et al. 2013). Some studies on northern peatlands found fungal communities to be dominant on surface peat layers (Newell et al. 1995; Kuehn et al. 2000) while other studies found bacterial communities to be dominant (Gilbert et al. 1998; Winsborough and Basiliko 2010). However for tropical forest, such studies are sparse. Hadi et al. (2001) measured greater bacterial than fungal biomass in both forest and paddy fields in Indonesian peatlands. In a rare study into microbial communities in Malaysian tropical peatlands, Jackson et al. (2009) found Acidobacteria to be the most dominant species in the bacterial community down to $50 \mathrm{~cm}$ depth, but did not study any eukaryotic soil communities. Similar trends of Acidobacteria dominance was also observed in forest, oil palm plantations and other disturbed peatlands in Indonesia (Mishra et al. 2014). Bacterial communities in Central American peatlands also had high proportion of Acidobacteria, but Proteobacteria were slightly higher in proportion than Acidobacteria (Troxler et al. 2012).

Too et al. (2018) observed significant change in microbial communities with depth in tropical peatlands, however the rhizosphere of different forest trees did not significantly influence change in microbial communities. Though the influence of vegetation on microbial communities is not yet clearly understood in the limited number of studies, the landscape level changes based on land-use in surface peat microbial community structure were evidently significant for different oil palm cropping systems and peat forests of different level of disturbances (Dhandapani et al. 2019a, b, c). Other than these mentioned studies, all the rest of the very few studies on microbes in tropical peatland focused on specific microbial functions such as activity and decomposition (Yule and Gomez 2009; Valenzuela et al. 2017), or on specific microbial groups (Voglmayr and Yule 2006; Hashidoko et al. 2008; Rahman et al. 2010; Arai et al. 2014). The lack of data and research on poorly understood peat microbial communities make it difficult to infer the structure and function of tropical peatland microbial communities and their response to disturbances in relation to land use change.

Analysis of ester-linked PLFA is an established method for phenotypic characterization of microbial communities (Kaur et al. 2005; Bloem et al. 2008; Frostegard et al. 2011). Phospholipids constitute $75 \%$ of the lipids in a cell membrane (Dowhan et al. 2016). The PLFAs respond to both intracellular and extracellular stress (Kaur et al. 2005), asserting the importance of PLFA analysis in monitoring soil microbes and their response to changes. A typical soil community phenotype profile obtained following PLFA analysis contains about 20 to 40 PLFAs (Bloem et al. 2008). Even though 
PLFA analysis, unlike genetic-based molecular methods, does not give precise information on specific species composition, it is an effective, rapid and sensitive tool for monitoring microbial communities' responses to the environmental changes (Kaur et al. 2005; Bloem et al. 2008; Frostegard et al. 2011). A major limitation for using PLFA analysis in this study is that PLFA analysis does not detect methanogenic archaea, a functionally important group in peatlands. Methanogenic archaea contain ether linked fatty acids in their cell wall (Gattinger et al. 2003), while PLFA analyses extracts only ester-linked phospholipids.

The objectives of this research were to investigate and explore the variation of tropical peat microbial communities associated with (i) different land uses corresponding to different stages of oil palm expansion (ii) different depth within those land use types, and identify the dominant microbial community for each land use class and depth. Although microbial community structure were known to respond to changes in land-use and depth in many other ecosystems, tropical peatlands are distinct landscapes and microbial communities and responses are virtually unknown. We hypothesised that microbial community structures were affected and altered by the disturbances involved with different stages of conversion from forest to oil palm plantation, considering the dramatic changes in hydrology, microclimate and above ground biodiversity associated with the forest conversion. Similarly, microbial communities were hypothesised to change with depth due to the difference in carbon quality between surface layers and deeper layers along with changes in hydrology and oxygen availability with depth.

\section{Materials and Methods}

\section{Study Sites}

Study sites were selected in North Selangor peat swamp forest (NSPSF) in Peninsular Malaysia $\left(3^{\circ} 34^{\prime} 32 \mathrm{~N} 101^{\circ} 15^{\prime} 44 \mathrm{E}\right)$ to represent land-use types involved in different stages of peatland conversion to oil palm plantations namely: (i) Historically drained secondary peat forest, hereafter denoted as 'Forest'; (ii) Recently drained peatland forest, denoted 'Drained'; (iii) Burnt peatland, denoted 'Burnt'; (iv) Recently cleared peatland with young oil palm plantation, denoted 'Young Oil Palm'; (v) Mature oil palm plantation, denoted 'Mature Oil Palm'.

North Selangor peat Swamp Forest (NSPSF) peatlands are about $10 \mathrm{~km}$ from the west coast of Malaysia (Yule and Gomez 2009). The Forest and Drained sites had similar above ground vegetation comprising Macaranga pruinosa (Miq.) Müll.Arg, Campnosperma coriaceum (Jack) Hallier f., Blumeodendron tokbrai (Blume) Kurz, Shorea platycarpa F.Heim, Parartocarpus venenosus Becc., Ixora grandiflora
Ker Gawl, Pternandra galeata Ridl., Stenoclaena palustris (Burm. f.) Bedd., Asplenium longissimum Baker, Nephrolepsis biserrata (Sw.) Schott, Crytostachys sp., Cyperus rotundus L., and Pandanus atrocarpus Griff. (Yule and Gomez 2009). The major difference between the two forested land use types is the deep drainage in drained land use type with 2 to $3 \mathrm{~m}$ wide ditches dug at every few hundred metres (Tonks et al. 2017). The Forest sites in this study are chosen in areas that are away from old drainage ditches, and areas that had not been logged in the last 40 years resulting in high canopy cover and density than Drained sites. The site properties are given in Table 1. The mean values for peat properties and changes with depth are given in Supplementary Information S1. The Burnt sites have been subject to regular burning, with the most recent being 1.5 2 years before sampling, resulting in open scrubland, dominated by ferns, some grasses and bare soil and no forested areas. The burnt sites were also drain blocked, resulting in above surface water table in those sites (Table 1). The Young and Mature oil palm sites have undergone both drainage and deforestation with oil palm plants 9 months old, and 10-15 years old respectively.

Sampling was carried out during the wet season from November - December 2014, with five independent replicate sites for each land use type: precise locations are listed in Supplementary Table 1. Forest replicate sites were spatially distributed over the whole NSPSF. Mature Oil Palm sites were spatially distributed on the southern edge of NSPSF. Drained forest and Young Oil Palm were constrained to two areas on the north-eastern edge of NSPSF. Burnt sites were constrained to one area on the southern edge of NSPSF. A total of 5 replicate cores were collected from each of the 5 land-use type, bringing the combined total to 25 cores. Each core was $52 \mathrm{~mm}$ in diameter. The peat depth varied between sites and the core depth covered $2 \mathrm{~m}$ for all locations except Site 3 of the mature oil palm sites (viz. $100 \mathrm{~cm}, 50 \mathrm{~cm}$ and $150 \mathrm{~cm}$ for Sites 3,4 and 5 respectively) and 2 forest sites $(150 \mathrm{~cm}$ each for Sites 2 and 3). The peat cores were then separated into $20 \mathrm{~cm}$ segments and freeze-dried. The methods used for physicochemical characterisation of the samples are given in Tonks et al. (2017). The physico-chemical characteristics measured by Tonks et al. (2017) were $\mathrm{pH}$, peat temperature, peat moisture content, total carbon and nitrogen content, bulk density and organic matter content.

\section{PLFA Extraction}

Microbial community phenotypic structure was determined by phospholipid fatty acid (PLFA) analysis as described in Dhandapani et al. (2019a, b, c); PLFAs were extracted from $1 \mathrm{~g}$ freeze-dried tropical peat (from each $20 \mathrm{~cm}$ segment of each core) samples using a modification of the method described by Frostegard et al. (1991). The lipids from peat were 
Table 1 GPS locations and environmental characteristics of sampling sites measured at the time of sampling (between 9 AM and 3 PM)

\begin{tabular}{|c|c|c|c|c|c|c|}
\hline Site & GPS Coordinates & $\begin{array}{l}\text { Surface moisture } \\
(\%)\end{array}$ & $\begin{array}{l}\text { Surface temperature } \\
\left({ }^{\circ} \mathrm{C}\right)\end{array}$ & $\begin{array}{l}\text { Air temperature } \\
\left({ }^{\circ} \mathrm{C}\right)\end{array}$ & $\begin{array}{l}\text { water table level } \\
(\mathrm{cm})\end{array}$ & $\begin{array}{l}\text { peat depth } \\
(\mathrm{cm})\end{array}$ \\
\hline Forest 1 & 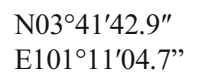 & 99.4 & 26 & 25.4 & 10 & 160 \\
\hline Forest 2 & $\begin{array}{l}\text { N03'29'02.4" } \\
\text { E101 } 15^{\prime} 07.3^{\prime \prime}\end{array}$ & 93.3 & 26 & 28.5 & -4 & 130 \\
\hline Forest 3 & $\begin{array}{l}\text { N034ㄴ'49.7" } \\
\text { E101 } 11^{\prime} 08.5^{\prime \prime}\end{array}$ & 34 & 26.6 & 28.1 & -27 & 80 \\
\hline Forest 4 & $\begin{array}{l}\text { N0329'55.6”' } \\
\text { E101 } 12^{\circ} 01.5^{\prime \prime}\end{array}$ & 100 & 26 & 27 & 21 & 160 \\
\hline Forest 5 & $\begin{array}{l}\text { N0339'08.2" } \\
\text { E101'17'43.4" }\end{array}$ & 100 & 25.8 & 27.6 & 30 & 415 \\
\hline Drained 1 & $\begin{array}{l}\text { N0338'51.3" } \\
\text { E101 } 20^{\circ} 32.6^{\prime \prime}\end{array}$ & 36.1 & 27.8 & 29 & -42 & 355 \\
\hline Drained 2 & 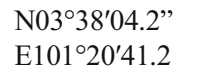 & 33 & 26.3 & 28.4 & -8 & 241 \\
\hline Drained 3 & 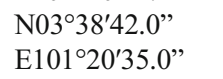 & 73.4 & 27.2 & 29.9 & 20 & 340 \\
\hline Drained 4 & $\begin{array}{l}\text { N0339'30.7" } \\
\text { E101 }{ }^{\circ} 19^{\prime} 19.9^{\prime \prime}\end{array}$ & 36.3 & 26 & 26.1 & -10 & 200 \\
\hline Drained 5 & $\begin{array}{l}\text { N03'39'34.2”' } \\
\text { E101'19'24.7”' }\end{array}$ & 52.9 & 26.9 & 27.4 & -30 & 200 \\
\hline Burnt 1 & $\begin{array}{l}\mathrm{N}^{\circ} 3^{\circ} 27^{\prime} 56.5^{\prime \prime} \\
\mathrm{E} 101^{\circ} 26^{\prime} 29.08^{\prime \prime}\end{array}$ & 99.33 & 28.13 & 26.2 & 30 & $*$ \\
\hline Burnt 2 & $\begin{array}{l}\text { N032ㄴ'53.1" } \\
\text { E101 } 20^{\circ} 12.6^{\prime \prime}\end{array}$ & 100 & 27.56 & 27.7 & 50 & 350 \\
\hline Burnt 3 & 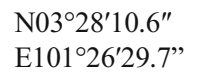 & 100 & 27.63 & 32.2 & 17 & 350 \\
\hline Burnt 4 & 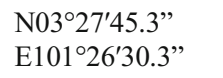 & 100 & 28.93 & 29.6 & 20 & 350 \\
\hline Burnt 5 & $\begin{array}{l}\mathrm{N} 03^{\circ} 25^{\prime} 56.2^{\prime \prime} \\
\mathrm{E} 101^{\circ} 20^{\prime} 14.0\end{array}$ & 100 & 27.23 & 27.4 & 40 & 265 \\
\hline Young OP 1 & $\begin{array}{l}\text { N0339'49.8”' } \\
\text { E101'20'38.1” }\end{array}$ & 39.02 & 29.63 & 26.6 & -60 & 315 \\
\hline Young OP 2 & 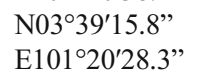 & 46.5 & 28.92 & 29.3 & -26 & 200 \\
\hline Young OP 3 & 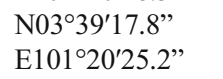 & 52.45 & 29.4 & 32.2 & -35 & 235 \\
\hline Young OP 4 & $\begin{array}{l}\text { N0339'43.6" } \\
\text { E101 } 19^{\prime} 42.5^{\prime \prime}\end{array}$ & 51.44 & 30.03 & 32 & -25 & 254 \\
\hline Young OP 5 & $\begin{array}{l}\text { N0339'40.2”' } \\
\text { E101'19'51.4" }\end{array}$ & 38.57 & 29.49 & 33.3 & -50 & 232 \\
\hline Mature OP 1 & $\begin{array}{l}\text { N03 } 24^{\prime} 43.6^{\prime \prime} \\
\text { E101 } 20^{\prime} 2.8^{\prime \prime}\end{array}$ & 44.59 & 27.99 & 28.8 & -47 & 180 \\
\hline Mature OP 2 & 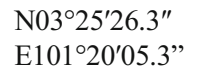 & 72.5 & 27.8 & 29.2 & -18 & 225 \\
\hline Mature OP 3 & $\begin{array}{l}\text { N0325'16.7" } \\
\text { E101 }{ }^{\circ} 19^{\prime} 48.6^{\prime \prime}\end{array}$ & 85.8 & 29.14 & 28.1 & -14.5 & 90 \\
\hline Mature OP 4 & $\begin{array}{l}\text { N032ㄱ'55.8 } \\
\text { E101 } 27^{\circ} 09.8^{\prime \prime}\end{array}$ & 63.12 & 27.55 & 25.6 & -5 & 130 \\
\hline Mature OP 5 & 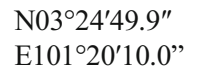 & 52.32 & 27.92 & 26.3 & 0 & 120 \\
\hline
\end{tabular}

extracted using Bligh \& Dyer extraction method (1959). The extracted lipids were then separated into neutral lipids, glycol lipids and polar lipids (containing phospholipids) fractions using Megabond Elut ${ }^{\circledR}$ silica gel column. The extracted polar lipids were then methylated by mild alkaline methanolysis and converted into fatty acid methyl esters, which were then run on gas chromatography.

\section{Gas Chromatography and Peak Identification}

The dried fatty acid methyl esters were suspended in $200 \mu \mathrm{l}$ of hexane, ready for GC injection. One $\mu$ l of each sample was injected into the GC in split-less mode. The column used in the GC for phospholipid analysis was 'ZB-FFAP' column, supplied by Phenomenex®. The column was $30 \mathrm{~m}$ length $\times$ 
$0.25 \mathrm{~mm}$ inner diameter $\times 0.25 \mu \mathrm{m}$ film thickness. The carrier gas was helium with the constant pressure of 18 psi. The initial oven temperature in $\mathrm{GC}$ was $120^{\circ} \mathrm{C}$; this was maintained for $1 \mathrm{~min}$ and then programmed to $250{ }^{\circ} \mathrm{C}$ at the rate of $5{ }^{\circ} \mathrm{C} \mathrm{min}{ }^{-1}$. The constant temperature of $250{ }^{\circ} \mathrm{C}$ was maintained throughout the run. The results were displayed as a chromatogram of retention times of the compounds and the mass spectroscopy provides the ion profile of each compounds.

The fatty acids i15:0, a15:0, i16:0, i17:0, a17:0 were considered as Gram-positive biomarkers (Wilkinson et al. 2002). The fatty acids 10me16:0 and 10me18:0 were described as the biomarkers for actinomycetes (Wilkinson et al. 2002; MooreKucera and Dick 2008), a group that belongs to Gram-positive bacteria. The relative abundance of Gram-negative bacteria was calculated using 16:1n9, 16:1n7, cyc17:0, 18:1n7 and cyc19:0 as biomarkers (Wilkinson et al. 2002; Kaiser et al. 2010). 18:2n6 and 18:1n9 were used as fungal biomarkers (Vestal and White 1989; Wilkinson et al. 2002; Kaiser et al. 2010). Fatty acids such as 14:0, 16:0, 18:0, a17:1 and 20:0 were non-specific to any particular group (Wilkinson et al. 2002). The fatty acids with similar mass spectrum $18: \ln 9$ and $18: \ln 7$ were differentiated with the help of neutral lipid fatty acid (NLFA) analysis, by the findings that fungal biomarker $18: \ln 9$ should have much higher NLFA/PLFA ratio than the Gram-negative biomarker 18:1n7 (Baath 2003). The ratio of Cyclopropane fatty acids (cyc17:0\& cyc19:0) to their monoenoic precursors $(16: \ln 7 \& 18: \ln 7)$ and the ratio of total saturated fatty acids $(14: 0,16: 0,18: 0,20: 0)$ to monounsaturated fatty acids $(16: \ln 9,16: \ln 7, a 17: \ln , 18: \ln 9$, $18: \ln 7)$ were used as indicators of stress (such as reduced carbon and nutrient availability) and other ecological conditions (such as flooding) (Bossio and Scow 1998).

\section{Statistical Analysis}

The statistical analyses were carried out using Genstat ${ }^{\circledR} 17$ th edition. Principal component (PC) analysis using correlation matrix was performed on PLFA data using Mol\% normalised spectra. Relative abundance of individual microbial groups, and ratios between groups, were calculated and were subjected to statistical analysis using restricted maximum likelihood (REML) models, to identify the interactions of individual microbial groups with land use type, depth and combination of land use type and depth. Similar REMLs were also performed for PCs. REML was carried out by applying 'land use type' and 'depth' as a fixed factor, while 'core number' was applied as a random factor. Microbial groups were further analysed using Tukey's multiple comparison tests, to establish the significance of differences between each individual land-use types. Backward stepwise multiple regression was performed with relative abundance of microbial groups as response variables and other environmental parameters as fitted terms, to identify the relationship between microbial relative abundance and peat characteristics measured by Tonks et al. (2017). Simple linear regression was performed for microbial groups and ratios, and depths to identify their changes with depth.

\section{Results}

Principal component (PC) analysis showed significant discrimination for both land-use and depth. PC1-4 collectively accounted for $57 \%$ of the variation, with PC2-4 each accounting for similar proportions of variation between 10 and $13 \%$ (Fig. 1). There were no significant interactions between landuse type and depth for any of PC1-4 (Table 2) and hence main effects of land-use type and depth can be considered separately.

\section{Effects of Land-Use Types}

Across all depths, there was highly significant discrimination between land-use types across all of PC1-4 (Table 2; Fig. 1ab). The primary nature of the discriminations were that $\mathrm{PC} 1$ separated Burnt from the other land-use types, and PC2 separated Forest from all the other land-use types. Young and Mature oil palm were strongly separated from each other by PC3, with the latter being distinct from all the other land-use types. Burnt land-use were intermediate to the others with respect to PC3. PC4 then separated Mature and Young Oil Palm from all others, which otherwise were clustered with respect to this component. The loadings for individual PLFAs associated with each of the PCs were generally dispersed, with no particular dominance of any single PLFA, and 20:0, 18:2n6 and 16:0 having very low loading scores (Fig. $1 \mathrm{c}-\mathrm{d})$. Notable exceptions were that $16: 0$ was particularly associated with the separation of Forest from all the other landuse types with respect to PC1 and 2 (Fig. 1a, c). Likewise, 14:0, 10me18, 17:1n and $i 17: 0$ were strongly associated with the distinctness of both Mature and Young Oil Palm land-uses with respect to PC4 (Fig. 1b, d).

\section{Variations along the Depth}

Across all treatments, PC1 and PC3 (collectively accounting for $35 \%$ of the variation; Fig. 2), varied significantly with respect to depth (Table 2). Both PCs showed a consistent and coherent relationship to depth, resulting in a distinct trajectory in the biplot (Fig. 2a). There was a distinct shift in this trajectory at around $1 \mathrm{~m}$ depth, below which PC2 showed little change (Fig. 2a). The loadings for individual PLFAs associated with each of the PCs were generally dispersed, with no particular dominance of any single PLFA and 18:2n and 14:0 having very low loading scores (Fig. 2b). 

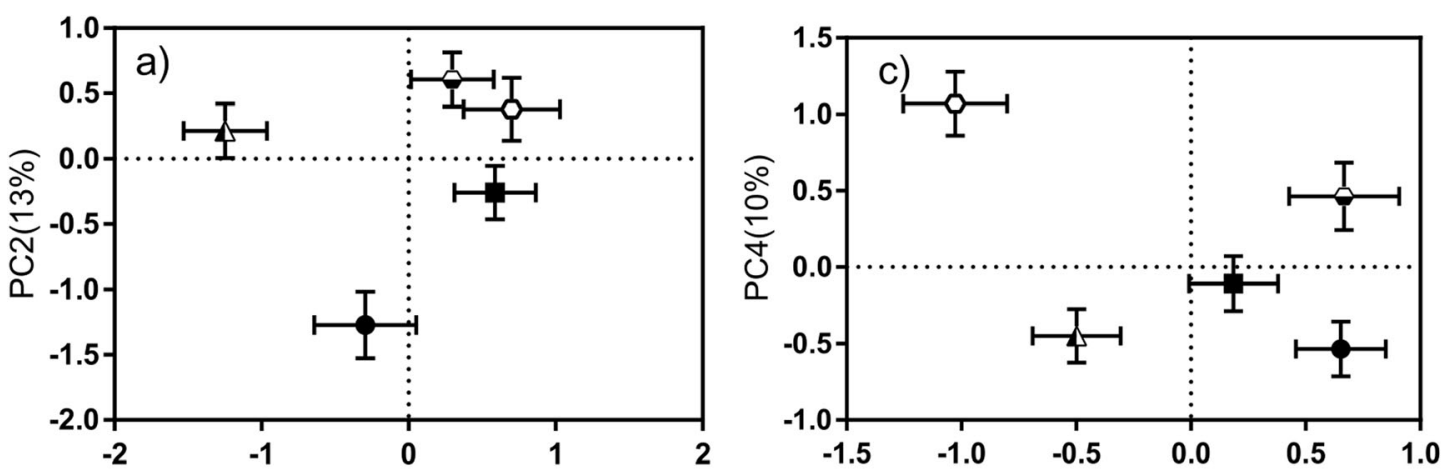

$\begin{array}{ll}\text { - } & \text { Forest } \\ \text { - } & \text { Drained } \\ \Delta & \text { Burnt } \\ \bullet & \text { Young OP } \\ \text { - } & \text { Mature OP }\end{array}$

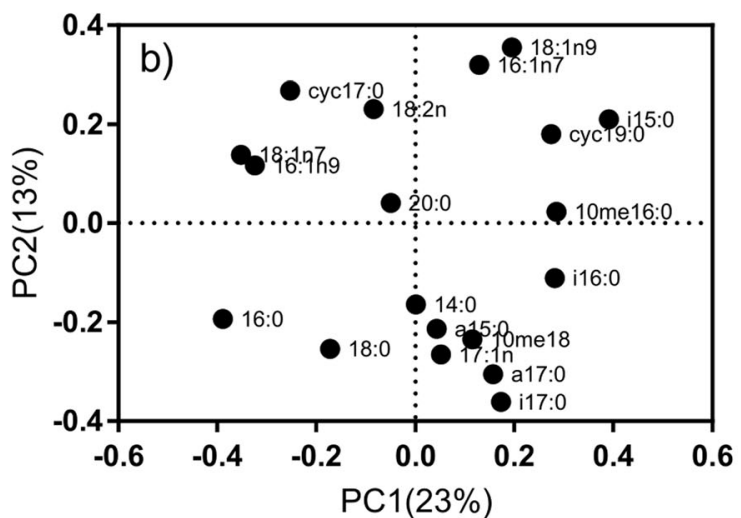

Fig. 1 Effect of land-use type (OP = oil palm) upon phenotypic structure of soil microbial communities determined by PLFA analysis, as shown by principal component (PC) analysis. a, b ordination of PC1 and 2 and

\section{Relative Abundance and Microbial Community Structure}

Only the proportion of Gram-negative bacteria, and fungi varied significantly between land-use type, with a significant interaction between land-use type and depth for fungi (Table 3). The statistical difference between the land-use types for fungal relative abundance was mainly driven by Forest, as here fungal relative abundance reduced with depth, while for all the other land-use types, the proportion of fungal markers was maintained across all depths (Fig. 3). Further Tukey's multiple comparison tests showed that Gram-negative relative abundance was significantly

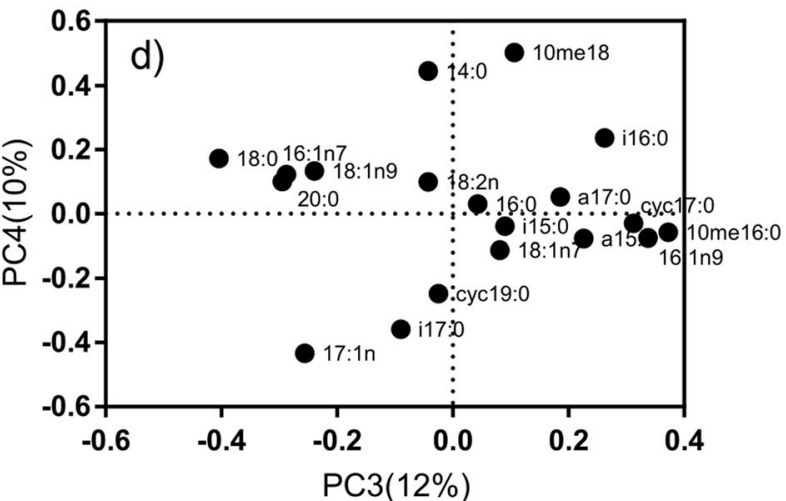

associated loadings for individual PLFAs; $\mathbf{c}, \mathbf{d}$ ordination of PC3 and PC4 and associated loadings, point labels denote PLFA type. For a, c points denote means ( $\mathrm{n}$ varies, see text), whiskers denote standard errors

different in Burnt land-use from all the rest of the land use types (Supplementary information S2). Mature Oil Palm had significantly different fungal relative abundance compared to Forest. Forest land-use was different from Young Oil Palm land-use in both Gram-negative and fungal relative abundance. Burnt land use had significantly different Gram-positive relative abundance to that of Drained and Forest land-use types. Actinomycetes did not significantly differ among any land-use types, and non-specific PLFAs differed only between Forest and Young Oil Palm. The ratio between Gram-negative and Gram-positive bacteria (G-:G+ ) differed significantly between Burnt land-use and all the rest of the land-use types except Mature Oil Palm. Mature

Table 2 Linear mixed model (REML) for principal component scores (PC1-4) obtained from aggregated PLFA data with respect to microbial groups, showing statistical significance of the effects of land-use type, depth and the interactions between land-use type and depth

\begin{tabular}{|c|c|c|c|c|c|c|c|c|c|c|c|c|}
\hline \multirow[t]{2}{*}{ REML } & \multicolumn{3}{|l|}{$\mathrm{PC} 1$} & \multicolumn{3}{|l|}{$\mathrm{PC} 2$} & \multicolumn{3}{|l|}{$\mathrm{PC} 3$} & \multicolumn{3}{|l|}{$\mathrm{PC} 4$} \\
\hline & $\mathrm{df}$ & F ratio & $\mathrm{p}$ & $\mathrm{df}$ & F ratio & $\mathrm{P}$ & $\mathrm{df}$ & F ratio & $\mathrm{p}$ & $\mathrm{df}$ & F ratio & $\mathrm{p}$ \\
\hline Land-use type & 4,165 & 14.6 & $<0.001$ & 4,165 & 8.59 & $<0.001$ & 4,165 & 12.57 & $<0.001$ & 4,165 & 12.29 & $<0.001$ \\
\hline Depth & 9,165 & 23.6 & $<0.001$ & 9,165 & 0.69 & 0.721 & 9,165 & 2.87 & 0.004 & 9,165 & 0.65 & 0.752 \\
\hline Land-use type*Depth & 36,165 & 0.77 & 0.817 & 36,165 & 0.48 & 0.994 & 36,165 & 0.92 & 0.608 & 36,165 & 1.42 & 0.072 \\
\hline
\end{tabular}

The 'p' values below ' 0.05 ' represent statistically significant effect 

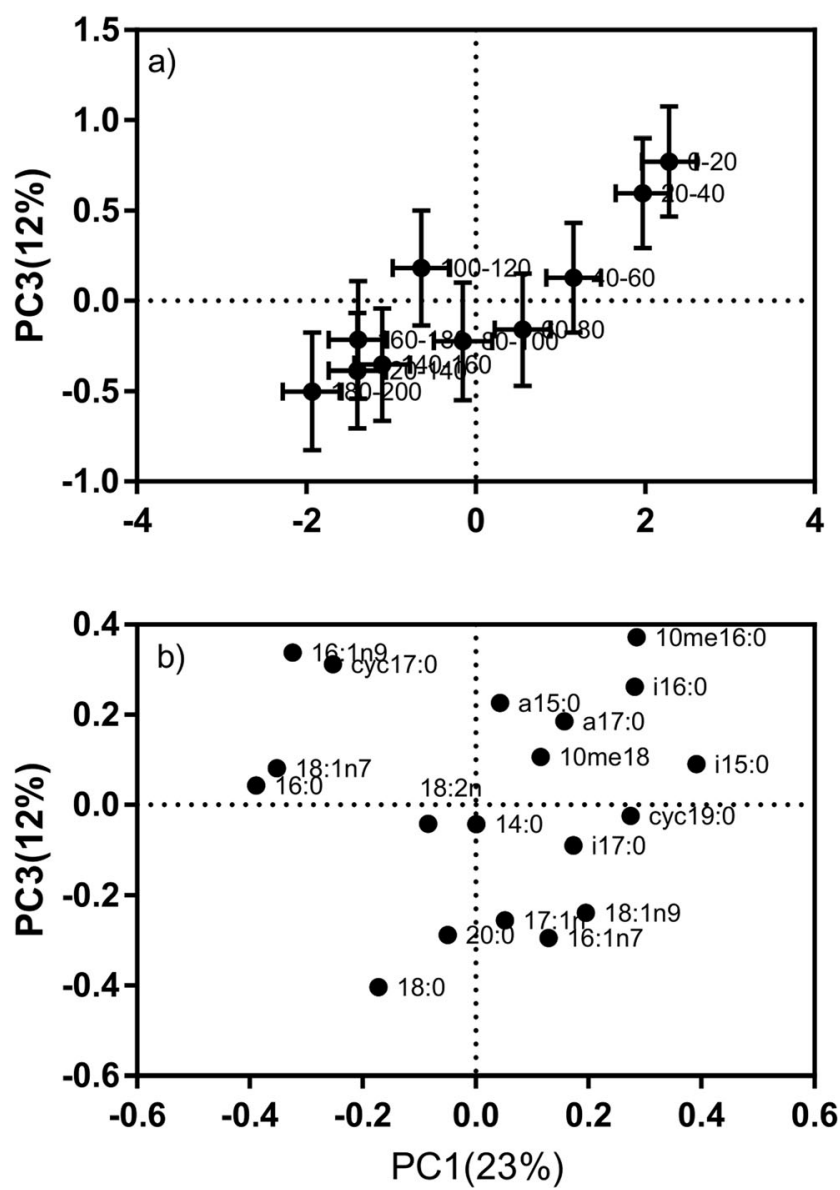

Fig. 2 Relationship between soil depth and phenotypic structure of soil microbial communities determined by PLFA analysis, as shown by principal component (PC) analysis. a ordination $\mathrm{PC1}$ and $\mathrm{PC} 3$; points denote means across all land-use types (n varies, see text $)(\mathrm{OP}=$ oil palm), whiskers denote standard errors. Point labels denote depth of sample in $\mathrm{cm}$ from surface; $\mathbf{b}$ associated loadings for individual PLFAs, point labels denote PLFA type

Oil Palm land-use had significantly different Fungi:bacteria $(\mathrm{F}: \mathrm{B})$ ratio to that of Burnt and Forest land-use types. The F:B ratio was also significantly different between Young Oil Palm and Forest land-use types. None of the microbial groups or ratios significantly differed among Drained,
Young Oil Palm and Mature Oil Palm land-use types (Supplementary information S2).

All the microbial groups showed significant changes with depth (Table 3). All of the land-use types were dominated by bacteria at all depths. Gram-positive bacteria (including the Gram-positive subgroup, actinomycetes) was the dominant group at the surface peat for all land-use types except for the Burnt peatland, where Gram-negative bacteria was the most dominant group at the surface by a large margin (Fig. 3). The proportion of Gram-positive bacteria decreased $(=25.343$ $0.07974 *$ depth $\left.\mathrm{cm} ; \mathrm{F}_{(1,214)}=126.45, p<0.001, \mathrm{R}^{2}=0.37\right)$ and that of non-specific fatty acids increased $(=22.6+0.0941 *$ depth $\left.\mathrm{cm} ; \mathrm{F}_{(1,214)}=84.94, \mathrm{p}<0.001, \mathrm{R}^{2}=0.28\right)$ with depth across all land uses. This decrease in proportion of Gram-positive biomarkers made way for the Gram-negative bacterial group $\left(=36.98+0.0208 *\right.$ depth $\mathrm{cm} ; \mathrm{F}_{(1,214)}=3.94, p=0.049, \mathrm{R}^{2}=$ 0.014 ) to be the dominant one with increasing depth, starting at 40-60 cm for Forest and $20-40 \mathrm{~cm}$ for all the other land-use types (Fig. 3). The relative abundance of fungal markers was less than $10 \%$ and slightly decreased $(=7.307-0.010 *$ depth $\mathrm{cm}$; $\left.\mathrm{F}_{(1,214)}=7.08, p=0.008, \mathrm{R}^{2}=0.028\right)$ maintaining a similar lower level across all depths, irrespective of the land-use types. The proportions of actinomycetes were also less than $10 \%$ across all land-use types, and followed a similar trend of decrease with depth $\left(=7.766-0.026 *\right.$ depth $\mathrm{cm} ; \mathrm{F}_{(1,214)}=49.63, \mathrm{p}<0.001$, $\mathrm{R}^{2}=0.185$ ) as other Gram-positive bacteria.

In general, the ratio between fungal and bacterial relative abundance $(\mathrm{F}: \mathrm{B})$ did not vary significantly with respect to depth $\left(\mathrm{F}_{(1,214)}=0.07, p=0.799\right.$; Fig. 4a). The ratio of Gramnegative to Gram-positive bacteria (G-:G+) generally increased with depth $\left(=0.863+0.015 *\right.$ depth $\mathrm{cm} ; \mathrm{F}_{(1,214)}=$ $39.53, \mathrm{p}<0.001, \mathrm{R}^{2}=0.153$ ) for all land-use types, but with different patterns of behaviour according to land-use type. Burnt land-use involved a rapid increase in ratio (G-:G+) down to $140 \mathrm{~cm}$ depth and decline thereafter, with a similar trend for Forest although more attenuated (Fig. 4b). Cleared, Mature and Young Oil Palm land-use showed a distinct G-:G+ ratio increase with depth commencing at $160 \mathrm{~cm}$ (Fig. 4b).

Table 3 Linear mixed model (REML) for microbial group relative abundances, showing statistical significance of the effects of land-use type, depth and the interaction between land-use type and depth

\begin{tabular}{|c|c|c|c|c|c|c|c|c|c|c|c|c|c|c|c|}
\hline \multirow[t]{2}{*}{ REML } & \multicolumn{3}{|l|}{ G+ } & \multicolumn{3}{|l|}{ Act } & \multicolumn{3}{|l|}{ G- } & \multicolumn{3}{|l|}{ Fungi } & \multicolumn{3}{|c|}{ Non-specific } \\
\hline & $\mathrm{df}$ & F ratio & $\mathrm{p}$ & $\mathrm{df}$ & F ratio & $\mathrm{p}$ & $\mathrm{df}$ & F ratio & $\mathrm{p}$ & df & F ratio & $\mathrm{p}$ & df & F ratio & $\mathrm{p}$ \\
\hline Land-use type & $4,19.6$ & 1.61 & 0.211 & 4,18 & 1.43 & 0.265 & $4,19.6$ & 4.11 & 0.014 & $4,19.8$ & 3.87 & 0.018 & $4,17.4$ & 2.65 & 0.069 \\
\hline Depth & 9,147 & 19 & $<0.001$ & 9,146 & 7.47 & $<0.001$ & 9,147 & 3.31 & 0.001 & 9,148 & 2.29 & 0.02 & 9,145 & 13.3 & $<0.001$ \\
\hline $\begin{array}{l}\text { Land-use } \\
\text { type*Depth }\end{array}$ & $\begin{array}{l}36 \\
147\end{array}$ & 1.23 & 0.198 & $\begin{array}{l}36, \\
147\end{array}$ & 1.23 & 0.194 & $\begin{array}{l}36, \\
147\end{array}$ & 0.17 & 0.168 & $\begin{array}{l}36, \\
148\end{array}$ & 1.65 & 0.021 & $\begin{array}{l}36, \\
146\end{array}$ & 0.97 & 0.531 \\
\hline
\end{tabular}

The 'p' values below ' 0.05 ' represent statistically significant effect.Gram-positive $(\mathrm{G}+)$ represents the sum of relative abundance of PLFAs $i 15: 0$, a 15:0, i16:0, i17:0 and a17:0. Actinomycetes (Act) represents the sum of 10me16:0 and 10me18:0. Gram-negative (G-) represents the sum of 16:1n9, 16:1n7, cyc17:0, 18:1n7 and cyc19:0. Fungi represents sum of 18:2n6 and 18:1n9. Non-specific represents the sum of 14:0, 16:0, 18:0, a17:1 and 20:0 
Fig. 3 Relative abundance of different microbial groups as determined by PLFA analysis in relation to soil depth ranges under a forested peatland; $\mathbf{b}$ drained peatland; $\mathbf{c}$ burnt peatland; $\mathbf{d}$ young oil palm (OP) plantation; e mature oil palm (OP) plantation. Points denote means (n varies, see text), whiskers denote standard errors
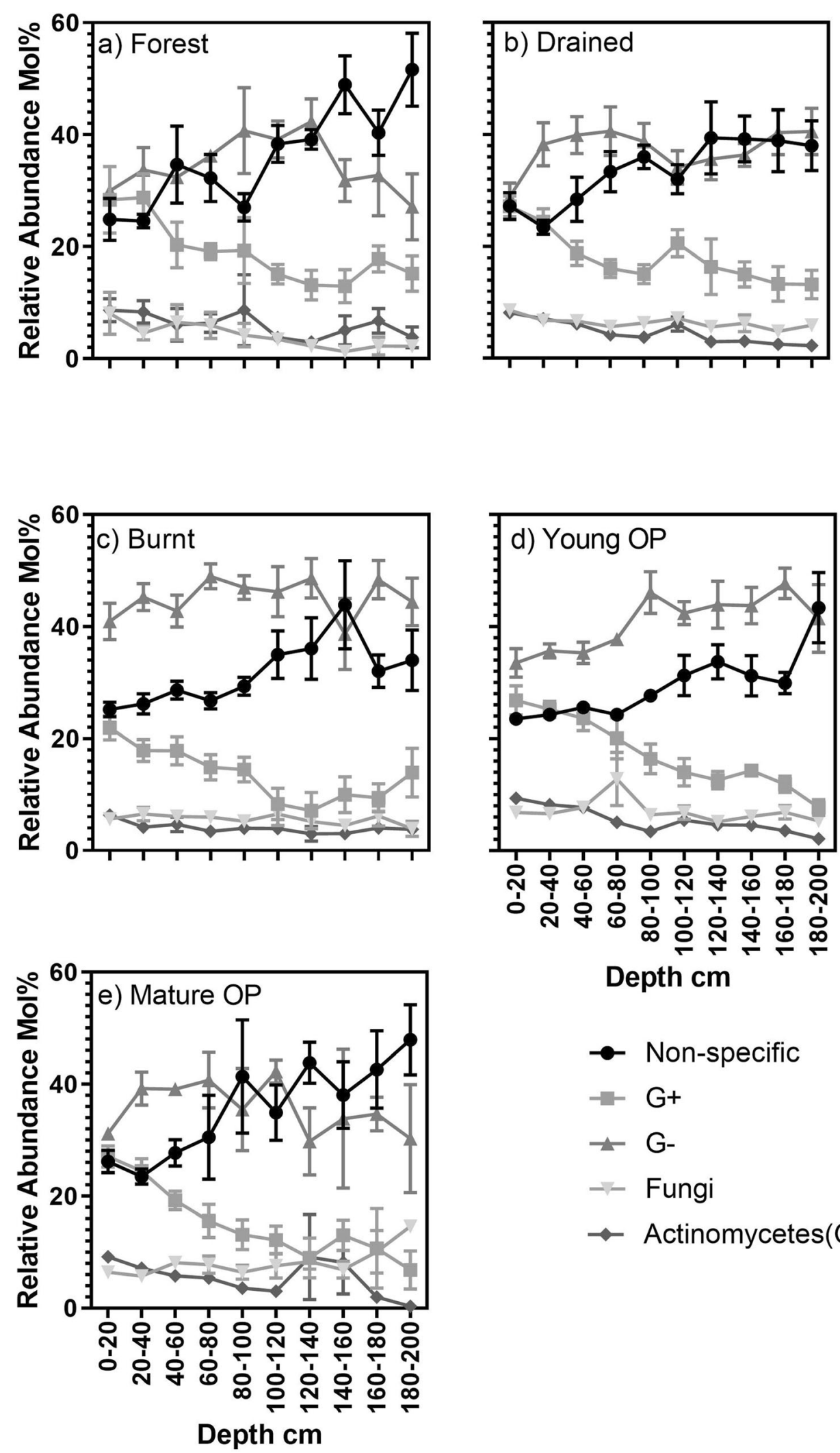

Principal component analysis using relative abundance of microbial groups strongly supported the variations between land-use types observed via principal component analysis of individual fatty acids (Supplementary information S3). PC1 and PC2 together accounted for $73 \%$ of the variations. PC1 separated out Burnt from all of the other land-use types, while 

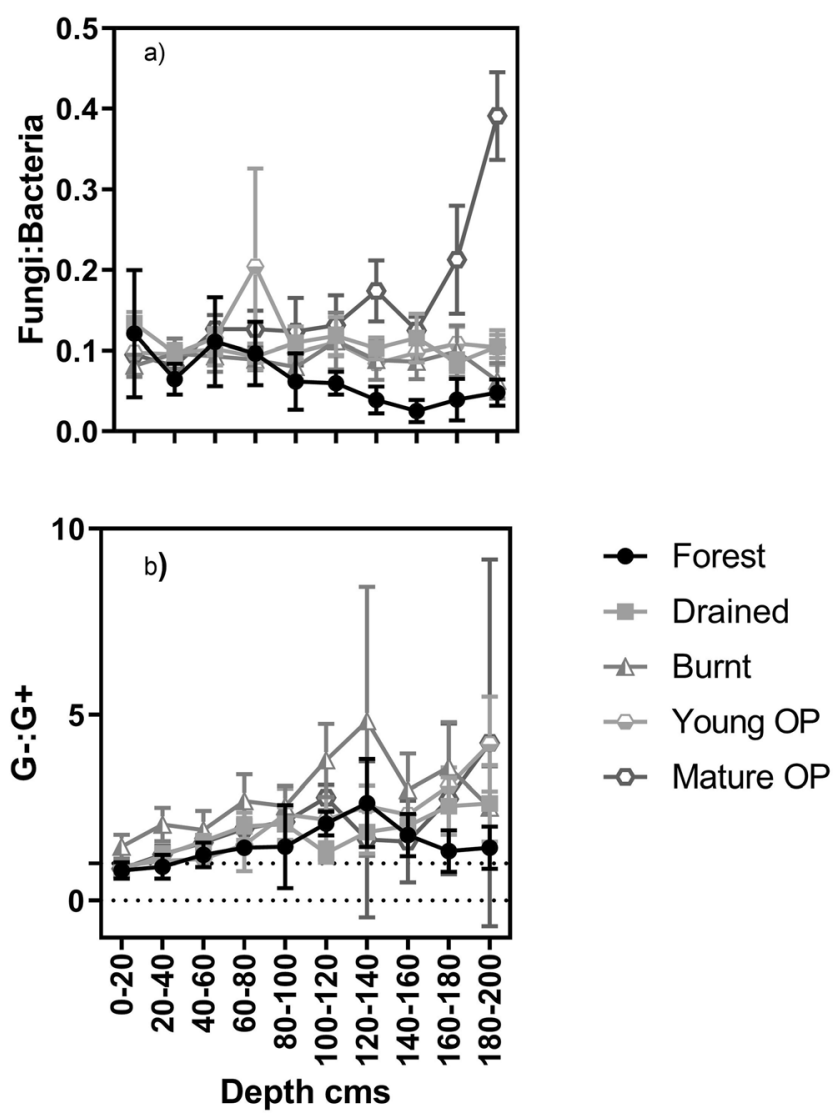

Fig. 4 Ratios of relative abundance of microbial groups across soil depth range under different land-use types $(\mathrm{OP}=$ oil palm). a ratio between the relative abundance of fungi and bacteria; $\mathbf{b}$ ratio between the relative abundance of Gram-negative bacteria and Gram-positive bacteria. Points denote means (n varies, see text), whiskers denote standard errors

PC2 separated Forest from the other land use types. Burnt land-use was separated farthest away from Forest by both the PCs, the changes with depth and a shift in pattern of change after a metre depth was also apparent in microbial group level PCs (Supplementary information S3).

\section{Other Ecological Indicators}

The ratio between cyclopropane fatty acids and their precursors (cyc:pre) decreased with depth for all the reported landuse types $\left(\mathrm{F}_{9,144}=15.75, \mathrm{p}<0.001\right)$, while the difference among land-use types, and interaction between land-use type and depth was not significant (Fig. 5). Burnt land-use had the lowest cyc:pre ratio in the surface peat layer and the changes with depth were minimal in Burnt compared to other land-use types. Simple linear regression showed a significant decrease of cyc:pre ratio with depth $(=2.878-0.017 *$ depth $\mathrm{cm}$; $\left.\mathrm{F}_{(1,214)}=81.45, \mathrm{p}<0.001, \mathrm{R}^{2}=0.273\right)$ for all land use types.

The ratio of total saturated fatty acids to monounsaturated fatty acids (sat:mono) varied with depth $\left(\mathrm{F}_{9,140}=1.98, p<0.05\right)$ and land-use types $\left(\mathrm{F}_{4,15}=3.76\right.$, $p<0.005$ ), but the interaction between land-use type and depth was insignificant. Forest, Drained and Mature Oil Palm had identical ratio at the surface, while Burnt and Young Oil Palm had identical lower ratio at the surface layer. The ratio increased for Forest and it either decreased or remained the same with depth for other land-use types. The Mature and Young Oil Palm land-use types had similar higher ratios at and after a metre depth. Burnt land-use type had the lowest sat:mono ratios across all depth ranges except for 140-160 cm. Simple linear regression could not identify significant change in sat:mono ratio with depth $\left(\mathrm{F}_{(1,214)}=2.57, p=0.110\right)$.

\section{Microbial PLFA Relative Abundance and Environmental Controls}

Overall, volumetric moisture was a significant predictor for most microbial groups and PLFA ratios (Figs. 6 and 7). Grampositive bacteria and fungi responded negatively, while Gramnegative bacteria responded positively to increase in volumetric moisture. Among ratios, G-:G+ responded positively and cyc:pre responded negatively to moisture. Other than the
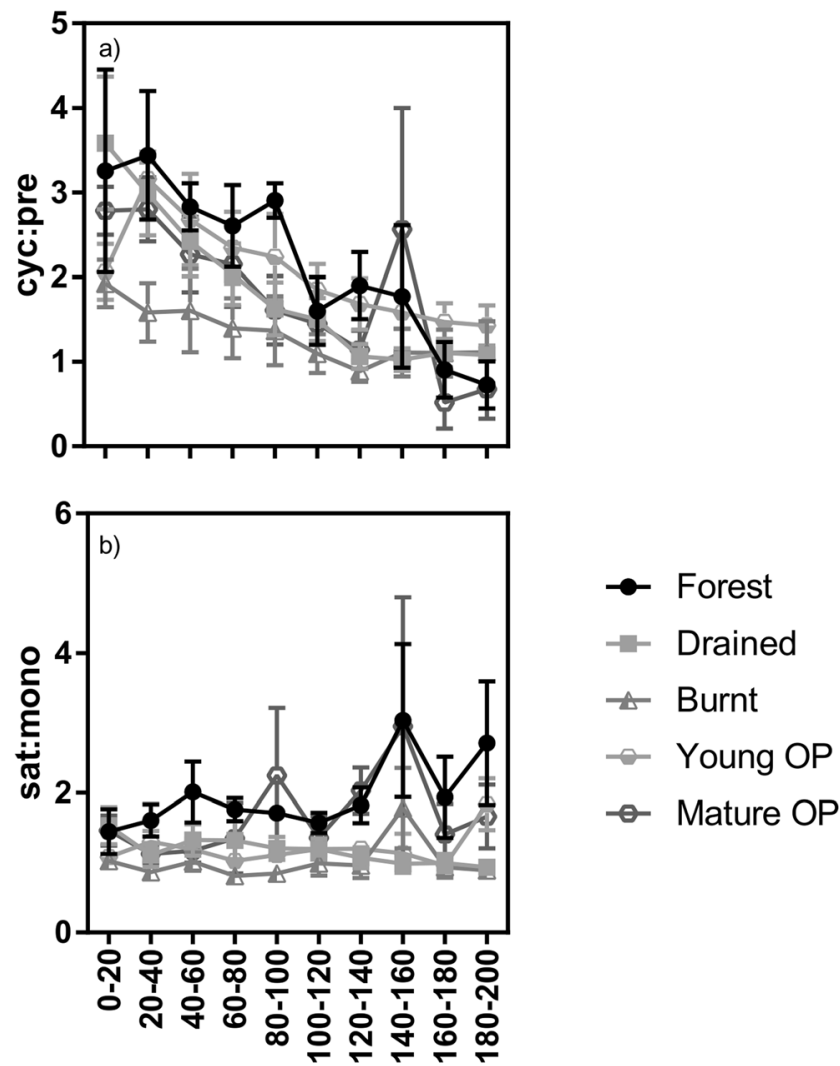

Fig. 5 PLFA ratios used as stress indicators as determined by PLFA analysis in relation to soil depth ranges under different land-use types $(\mathrm{OP}=$ oil palm) . a ratio between cyclopropance fatty acids and their precursors; $\mathbf{b}$ ratio between saturated fatty acids and mono-unsaturated fatty acids. See text for further details regarding derivation and interpretation. Points denote means (n varies, see text), whiskers denote standard errors 
responses to volumetric moisture, actinomycetes positively responded to bulk density (Fig. 6a) and negatively to $\mathrm{C}: \mathrm{N}$ (Fig. 6b), Gram-positive bacteria responded positively to bulk density, and fungi responded positively to organic matter content. Relative abundance of non-specific fatty acids and $\mathrm{F}: \mathrm{B}$ responded positively to $\mathrm{C}: \mathrm{N}$ and organic matter content respectively. Cyc:pre and Sat:mono were negatively correlated with $\mathrm{C}: \mathrm{N}$ and organic matter content respectively.

\section{Discussion}

\section{Microbes under Different Land-Use Types}

This research compared sites at different stages of oil palm conversion from forest, including draining of forest, followed by clearing, or burning in some cases, and establishing oil palm plantations. Microbial phenotypic community structure
Fig. 6 Relationship between a Actinomycetes and bulk density b Actinomycetes and

Carbon:Nitrogen ratio c Grampositive bacteria and Nitrogen $\mathbf{d}$ Gram-positive bacteria and volumetric moisture e Gram-negative bacteria and bulk density f Gramnegative bacteria and volumetric moisture $\mathbf{g}$ Fungi and organic matter content $\mathbf{h}$ Fungi and volumetric moisture. The regression equation is not shown for $\mathbf{a}, \mathbf{g}$ and $\mathbf{h}$ as the models were poor fit with $\mathrm{R}^{2}$ lower than 0.05 a)

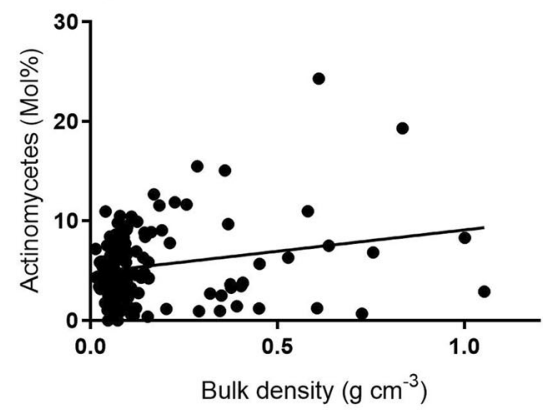

c)

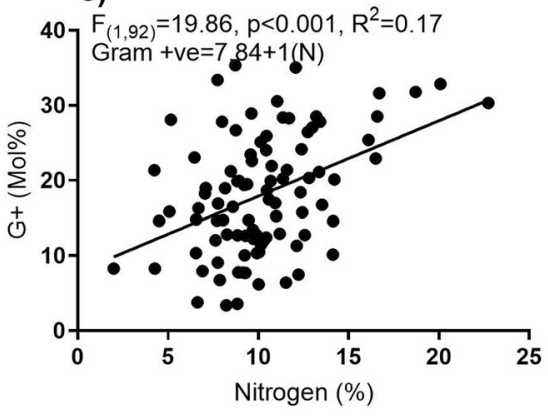

e) $F_{(1,165)}=26.95, p<0.001, R^{2}=0.14$
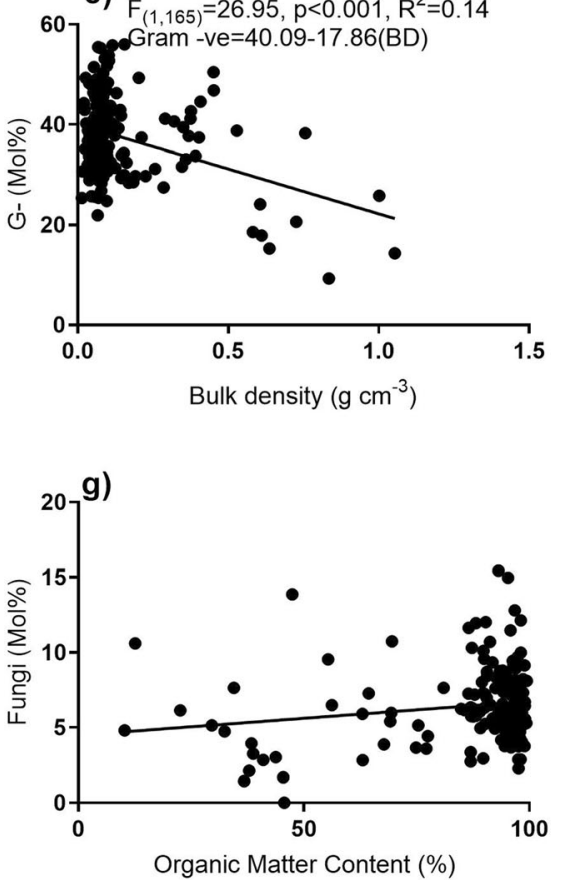

b)

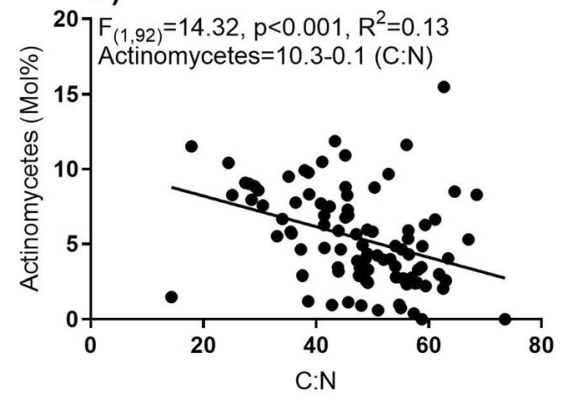

d)

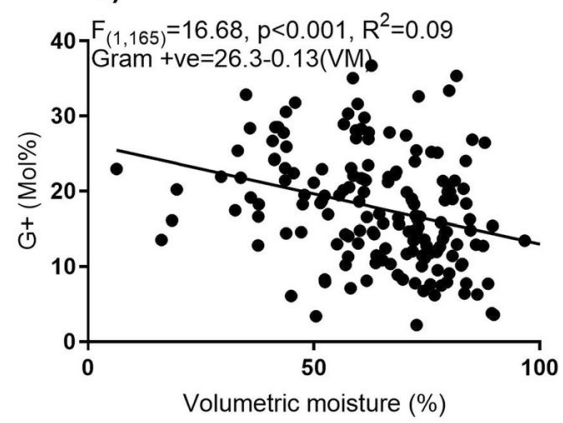

f)

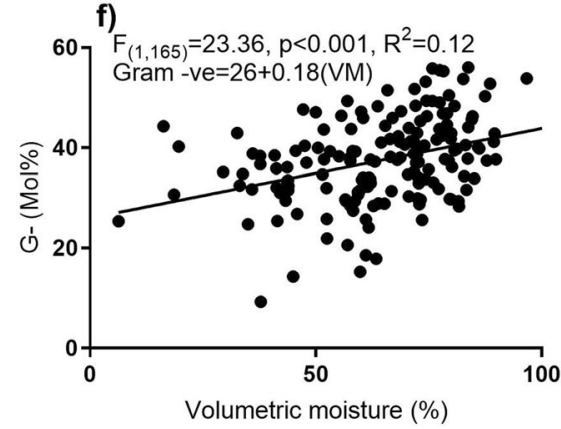

h)

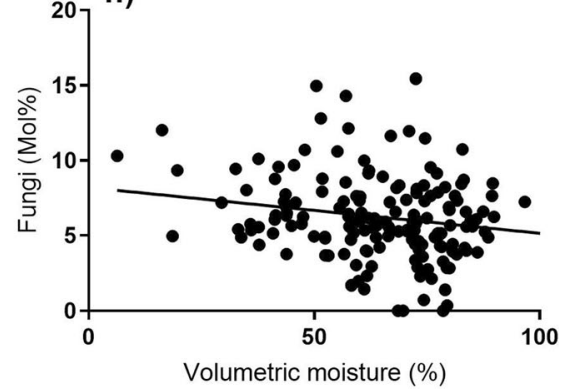


Fig. 7 Relationship between a Non-specific fatty acids and Carbon:Nitrogen ratio b Log Gram-negative:Gram-positive ratio and volumetric moisture $\mathbf{c} \log$ fungi:bacteria ratio and organic matter content $\mathbf{d}$

Cycyclopropane:precursors fatty acid ratio and volumetric moisture e Cyclopropane:precursors fatty acid ratio and carbon:nitrogen ratio $\mathbf{f} \log$

Saturated:monounsaturated fatty acid ratio and organic matter content. The regression equation is not shown for $\mathbf{c}$, as the model was a poor fit with $\mathrm{R}^{2}$ lower than 0.05

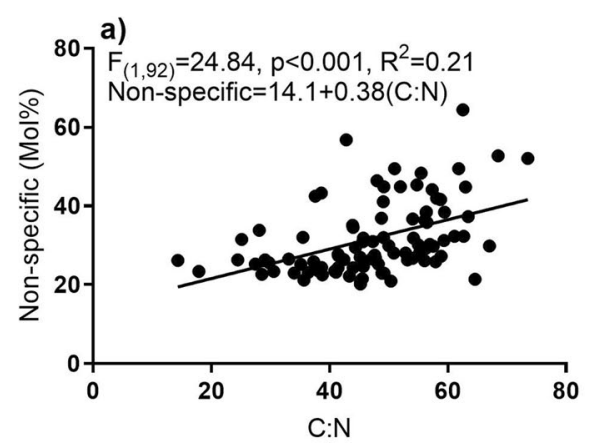

c)

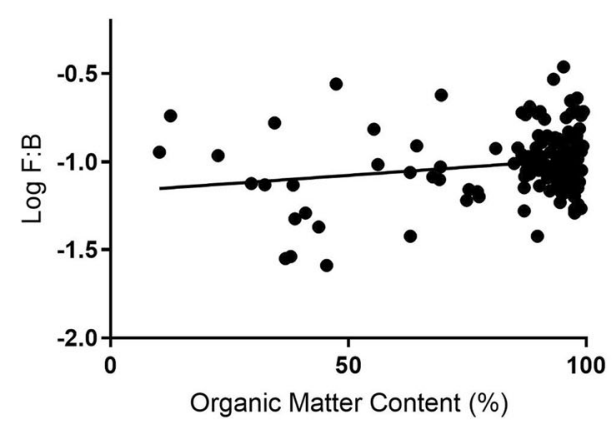

e)

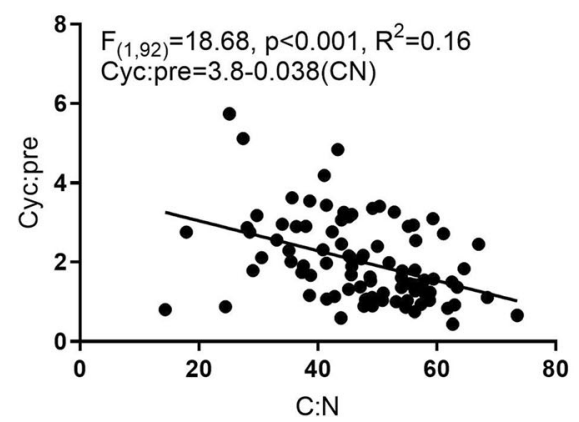

b)

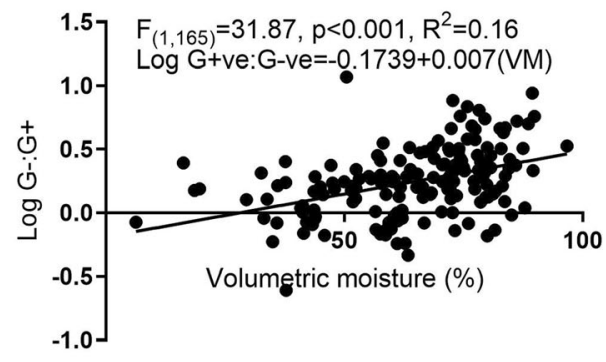

d)

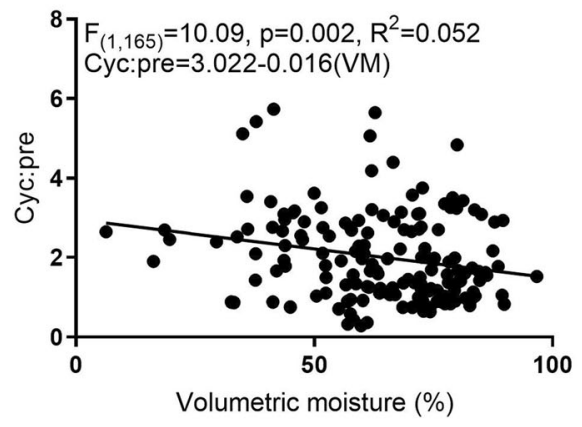

f)

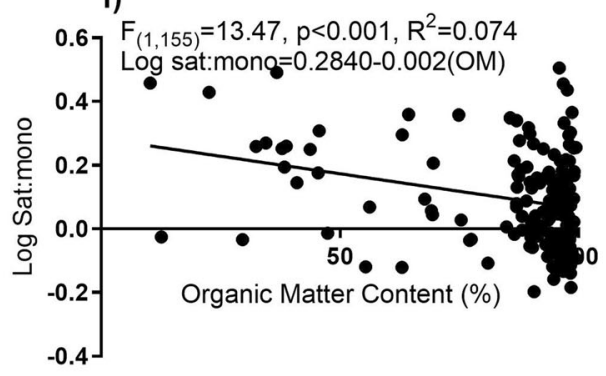

throughout the depth of $2 \mathrm{~m}$ in tropical peatlands are distinct for each land-use type. These five types of land-use along with other managed production forest, cover most of South East Asian peatlands (Miettinen et al. 2012; Miettinen et al. 2016). Given the environmental changes that accompany these land uses and changes in physico-chemical properties at different stages of conversion (Tonks et al. 2017), it is not surprising to see that they have significantly different microbial phenotypic community structure. As expected, Forest had notably distinct microbial communities, while the Drained peatlands had microbial communities that was similar to those in oil palm plantations. The Young Oil Palm plantation site in this study was a recently converted forest land, cleared without the use of fire. It is not uncommon to use fire to clear sites for oil palm plantation or use/claim fire affected sites for plantations, even though legislation in both Indonesia and Malaysia prohibits it (Varkkey 2013, 2016). It is highly likely that oil palm plantations established on fire affected site would have very different microbial community structure to that of oil palm plantation in this study, as our results have shown that oil palm plantations and burning changes microbial communities in different ways.

The Burnt land-use was distinct from other land-use types because of high relative abundance of primarily Gramnegative biomarkers namely $18: 1 n 7,16: 1 n 9$ and cyc17:0. This is possibly due to higher water table in the Burnt land- 
use because of drain blocking (Table 1). Gram-negative relative abundance positively correlated with volumetric moisture. Similar correlations were also reported by Dhandapani et al. (2019b), where primary peat forest with above surface water table, was dominated by Gram-negative bacteria.

\section{Consistent and Coherent Changes with Depth Irrespective of the Land Use}

The observed change in community structure with depth, may be influenced by several factors such as water table level, availability of oxygen and other nutrients, quality of $\mathrm{C}$, and other energy constraints, along the peat depth gradient (Andersen et al. 2013). This change with depth in Forest land-use was anticipated, as the surface microbial communities in North Selangor peat forest were dependent on C leached from leaf litter (Yule 2010), and the microbial communities were expected to change with changes in $\mathrm{C}$ source and quality with depth (Artz et al. 2007). However, similar changes with depth were also observed in other land-use types, including Burnt, Mature and Young Oil Palm landuse types, all of which lack a leaf litter layer in the surface, indicating that there are more factors than altered litter input driving this change in community structure.

Research conducted using genetic analyses in Northern peatlands show vertical stratification of microbes, with typically greatest microbial diversity and abundance in the intermediate depth because of the co-existence of oxic and anoxic layers, and reduction in diversity with increasing depth thereafter (Andersen et al. 2013). It is not known whether tropical peatlands follow similar pattern and it was beyond the scope of this study. However, Too et al. (2018) also found decrease in diversity in 45 and $90 \mathrm{~cm}$ depths compared to the surface layers in NSPSF, and $16 \mathrm{~S} r R N A$ sequencing by Jackson et al. (2009) found that microbial diversity decreased with depth (down to $50 \mathrm{~cm}$ ) in North Selangor peatlands, suggesting vertical stratification at least in surface layers. It is interesting that the relative abundance and the community dominance of the Gram-positive bacteria were also diminished with depth. There is a need for further research to understand if the loss of Gram-positive diversity with depth (Jackson et al. 2009) affected their community dominance over other microbial community groups.

Increase in non-specific fatty acids, with decrease in Grampositive bacteria influenced the change with depth below the surface, however further species level studies are required to further understand the dynamics of this change. The fungal relative abundances were low throughout the depth, contrary to the finding in northern hemisphere where fungi dominate the surface aerobic layers in natural forest ecosystems (Bardgett 2005; Winsborough and Basiliko 2010). Gramnegative bacteria either remained unchanged or increased slightly with depth. This is likely be due to the increase in
C:N ratio with depth (Supplementary Information 3; Tonks et al. 2017), which favours Gram-negative bacteria (Bossio and Scow 1998; Liu et al. 2015). A sudden spike in F:B and G-:G+ ratios at the deepest layers of mature oil palm plantations may be due to a sudden and extreme change in soil properties due to the presence of a mineral layer at the greatest depths, as the depth of the peat cores in mature oil palm were very shallow compared to the other land-use types (Tonks et al. 2017).

This distinct shift in microbial community structure after a metre depth was not directly related to the water table level, as water table levels varied between different land use types during the time of sampling and they were not at a metre depth at any of the studied sites (Table 1; Tonks et al. 2017). Reasons for the shift in microbial communities after about a metre depth are therefore unclear. However, it is possible that the old peat deposits below a metre depth at the catotelm (Morris et al. 2011) are dense and recalcitrant (Tonks et al. 2017; Cooper et al. 2019), causing changes in microbial communities through changes in bulk density and hence blocking water movement (Andersen et al. 2013). There is a possibility that archaeal communities also occur at that depth range in North Selangor peatlands (Too et al. 2018), however the impact of their occurrence on other microbial communities are unknown. Jackson et al. (2009) did not find methanogens in the first $50 \mathrm{~cm}$ from the peat surface in North Selangor peatlands, however Too et al. (2018) found increased richness of archaea at $90 \mathrm{~cm}$ depth in the same North Selangor peatlands. Similarly, methanogens were found to be abundant at $30-40 \mathrm{~cm}$ below the water table in Northern Peatlands (Galand et al. 2002; Lin et al. 2014). Tropical peatlands may exhibit similar pattern for the occurrence of methanogens, which is at approximately $1 \mathrm{~m}$ depth in North Selangor peatlands when accounting for long-term water table draw down levels in most of our studied sites (Tonks et al. 2017). As PLFA analyses do not detect methanogenic archaeal communities, due to their ether link phospholipid cell membranes (Gattinger et al. 2003), rather than ester linked fatty acids found in other bacteria and fungi, there is a knowledge gap in addressing the shift, the occurrence of methanogenic communities and their relationship. Future studies may use molecular genetic techniques to characterise archaeal communities and also identify the shift at a metre depth.

\section{Bacterial Dominance in Community Structure}

The generally observed pattern in previous studies in different ecosystems are for bacterial dominance in heavily disturbed or intensive agricultural sites, while the sites with lesser disturbance, more acidic conditions and greater input of complex organic matters in natural habitats tend to favour fungal dominance (Bossuyt et al. 2001; Bardgett 2005; Fierer et al. 2009). This did not hold true for the Malaysian tropical peatlands, as 
all of the studied land-uses were clearly dominated by bacterial groups across all depths. This leads to the question of whether the removal of bigger dipterocarp trees by historical selective logging (Saiful and Latiff 2014) affected ectomycorrhizal fungal communities (Lee et al. 2010; Brearley 2012), However Too et al. (2018) studied three species of trees including one from Dipterocarpaceae in NSPSF and found that tree species did not significantly influence any changes in microbial community composition in surface and along the peat depth. Additionally, it has also been found that the surface peat layers of primary peat swamp forests in a different location within Peninsular Malaysia that had no known history of disturbance, was also overwhelmingly dominated by bacteria over fungi in the community structure (Dhandapani et al. 2019b). So it is highly plausible that tropical peatlands are inherently dominated by bacteria.

All the surface layers, except for the Burnt land-use were dominated by Gram-positive bacteria, but soon were replaced by Gram-negative bacteria, with increasing depth, possibly due to changes in moisture conditions and $\mathrm{C}: \mathrm{N}$ ratios (Fig. 7b; Supplementary information 3). Jackson et al. (2009) also found similar results with Acidobacteria, a phylum belonging to Gram-negative bacterial group, being the single biggest group from surface to $50 \mathrm{~cm}$, with considerable increase in their proportion at $50 \mathrm{~cm}$, the deepest layer in their study. All the studied peat sites had higher nitrogen content in the surface (supplementary information 3), which favoured Gram-positive bacteria (Fig. 6c) over Gram-negative bacteria. This is in agreement with study by Liu et al. (2015), who found that Gram-negative PLFA abundance decreased with the addition of nitrogen irrespective of the land use type in humid tropical forests in Southern China. A similar trend of increase in Gram-positive bacteria over Gram-negative bacteria with decreased $\mathrm{C}: \mathrm{N}$ was also observed in other tropical soils (Smith et al. 2014).

The dominance of Gram-positive bacteria over Gramnegative bacteria on Forest and plantation peat surface layers, is in contradiction with what was observed in Panamanian peatlands, where Acidobacteria and Proteobacteria, both Gram-negatives, together constituted $68-80 \%$ of bacterial communities on surface of peat forest (Troxler et al. 2012). Similarly, surface layers of pristine peat forests in Terengganu were also found to be dominated by Gram-negative bacteria (Dhandapani et al. 2019b). This contrast may possibly be due to the difference in water table level between primary and secondary peat swamp forests (Dhandapani et al. 2019b), as reflected by Gram-negative dominance in surface peat layers of Burnt sites, that were submerged due to drain blocking (Table 1). This theory is supported by contrasting significant correlations exhibited by Gram-negative and Gram-positive microbial groups to moisture level (Fig. 6f, d). Jackson et al. (2009) found extracellular enzyme activities were greatest at the peat surface and decreased with depth at the North
Selangor peat swamp forest, which corresponds with relative abundance of Gram-positive bacteria. This suggests that Gram-positive bacteria is the most dominant group involved in extracellular enzyme activity and $\mathrm{C}$ mineralization in this tropical peatland. Actinomycetes were found to be more active at higher $\mathrm{pH}$ (Charousová et al. 2017). Higher $\mathrm{pH}$ is also known to support higher bacterial diversity in oil palm plantations on mineral soil (Tripathi et al. 2012; Wood et al. 2017). Even though $\mathrm{pH}$ was higher in the plantations than the forest, it was still under $\mathrm{pH} 4$ (Tonks et al. 2017) and did not affect the relative abundance of actinomycetes. This slight increase in $\mathrm{pH}$ with establishment of plantations in peatlands, may not be high enough to support increased bacterial diversity, as seen on plantations in mineral soil. Though this study does not indicate bacterial diversity, the ratio of fungi to bacteria were generally higher in Mature Oil Palm plantations (Fig. 4), showing that the slight increase in $\mathrm{pH}$ did not favour the bacterial community in peatlands. Actinomycetes, despite being Gram-positive bacteria, are more similar to fungi in structure and functions, while being much smaller in size to that of fungi (Barka et al. 2016). It is interesting to see that they exhibit similar trends throughout the depth at different land uses, and also both exhibiting negative correlations to moisture (Figs. $6 \mathrm{~b}$ and $\mathrm{h}$ ). These data are in agreement with those of Bossio and Scow (1998) and likewise their conclusion that fungal PLFA markers were less abundant in submerged systems.

\section{Is there Greater Nutritional Stress under Forest?}

Microbes transform some fatty acids in their cell membranes to more stable compounds as an adaptation to maintain functional living cell membranes during stressful conditions (Kaur et al. 2005). The fatty acids $c y c$ 17:0 and cyc 19:0 are formed by transmethylation of $16: \ln 7$ and $18: \ln 7$ (Kaur et al. 2005). This transmethylation was found to be a modification in cell membranes to minimize cellular degradation and membrane losses at the times of stressful conditions (Kaur et al. 2005). The higher ratio between $c y c 17: 0+c y c 19: 0$ and their precursors $16: \ln 7+18: \ln 7$ is used as a stress indicator for starvation and nutritional stress, due to low $\mathrm{C}$, high acidity and low oxygen (Kieft et al. 1994; Bossio and Scow 1998; Wilkinson et al. 2002; Liu et al. 2015). The ratio was found to decrease with high substrate availability (Bossio and Scow 1998). The ratio did not significantly differ between sites, however decreased with depth, implying decrease in stress level with depth (Fig. 5a). This decrease in ratio was related to an increase in C:N ratio with depth (Fig. 7e). Increase in $\mathrm{C}$ availability increases mono-unsaturated fatty acids, resulting in a decrease of cyc:pre ratios. Several studies suggest that an increase in the ratio of saturated fatty acids to mono-unsaturated fatty acids is an indicator of nutritional stress (Zelles et al. 1992; Kieft et al. 1994; Bossio and Scow 1998; Moore- 
Kucera and Dick 2008). This ratio was highest at the Forest and lowest at the Burnt land-use. The ratio thus suggests Forest land-use to be nutritionally stressed. It is known that burning makes more nutrients available in peatlands (Turetsky et al. 2015) while the natural tropical peatland habitats are naturally nutrient poor (Sjögersten et al. 2011). However, it should be noted that even though these ratios are widely used as indicators of stress (Willers et al. 2015), the change in ratio could simply be because of the shifts in microbial community structure (Frostegard et al. 2011). Irrespective, the combination of all the results show that Burnt land-use had the most different microbial communities from the Forest, among the studied land-uses of anthropogenic disturbances.

\section{Conclusions}

This study has demonstrated that bacteria dominate the microbial community structure in tropical peatlands irrespective of the land use and depth, however the microbial phenotypic structure also strongly responds to anthropogenic disturbances and vary with peat depth irrespective of the land-use. Burnt peatland and oil palm plantations were found to differently affect the soil microbial communities. Though the fatty acid composition varied the most from Forest in both Mature Oil Palm plantations and Burnt peatlands, changes in overall phenotypic structure of microbial communities were relatively less in Mature Oil Palm compared to Burnt land-use, which had the most different microbial phenotypic structure to that of the Forest. However, these changes in microbial phenotypic community structure were found to be closely associated with moisture and water table levels than other characteristics of the land-use. Fatty acid ratios used as ecological indicators also point towards Burnt peatland to have the most different microbial communities to that of peat Forest. Future research should focus on understanding species-level alterations and functional roles of each microbial species with land-use change and fire, and environmental controls on these microbial communities, as the changes in functions of microbial communities in these carbon rich ecosystems could have consequences well beyond the border of their respective ecosystems. Considering that microbes play a major role in the formation and sustenance of peatlands, as well as the amount and species of GHG emissions, incorporating these understandings to microbial processes, their environmental interactions and functional roles into wider peat management plan is critical for improving peat restoration efforts in South East Asia.

Acknowledgements We would like to thank Dr. Robert Linforth for help with gas chromotography, and other lab technicians in Agriculture and Environmental Science division at the University of Nottingham. We would also like to thank Dr. Mark Pawlett and lab technicians at Cranfield University for helping with PLFA lab procedure. We are thankful to Selangor State Forestry Department, PKPS Agricultural
Development Corporation and Global Environment Centre, Selangor, for granting site access and in-field assistance.

Funding information This work was supported by Crops For the Future (CFF), Malaysia [BioP1-011] and the School of Biosciences, University of Nottingham, UK.

Open Access This article is licensed under a Creative Commons Attribution 4.0 International License, which permits use, sharing, adaptation, distribution and reproduction in any medium or format, as long as you give appropriate credit to the original author(s) and the source, provide a link to the Creative Commons licence, and indicate if changes were made. The images or other third party material in this article are included in the article's Creative Commons licence, unless indicated otherwise in a credit line to the material. If material is not included in the article's Creative Commons licence and your intended use is not permitted by statutory regulation or exceeds the permitted use, you will need to obtain permission directly from the copyright holder. To view a copy of this licence, visit http://creativecommons.org/licenses/by/4.0/.

\section{References}

Andersen R, Chapman SJ, Artz RRE (2013) Microbial communities in natural and disturbed peatlands: a review. Soil Biology \& Biochemistry 57:979-994

Arai H, Hadi A, Darung U, Limin SH, Hatano R, Inubushi K (2014) A methanotrophic community in a tropical peatland is unaffected by drainage and forest fires in a tropical peat soil. Soil Science and Plant Nutrition 60:577-585

Artz RRE, Anderson IC, Chapman SJ, Hagn A, Schloter M, Potts JM, Campbell CD (2007) Changes in fungal community composition in response to vegetational succession during the natural regeneration of cutover peatlands. Microbial Ecology 54:508-522

Asemaninejad A, Thorn RG, Lindo Z (2017) Vertical distribution of fungi in hollows and hummocks of boreal peatlands. Fungal Ecology 27:59-68

Azhar B, Lindenmayer DB, Wood J, Fischer J, Manning A, McElhinny C, Zakaria M (2011) The conservation value of oil palm plantation estates, smallholdings and logged peat swamp forest for birds. Forest Ecology and Management 262:2306-2315

Baath E (2003) The use of neutral lipid fatty acids to indicate the physiological conditions of soil fungi. Microbial Ecology 45:373-383

Bardgett R (2005) The biology of soil : a community and ecosystem approach. Oxford University Press, New York

Barka EA, Vatsa P, Sanchez L, Gaveau-Vaillant N, Jacquard C, Klenk HP, Clément C, Ouhdouch Y, van Wezel GP (2016) Taxonomy, physiology, and natural products of Actinobacteria. Microbiology and Molecular Biology Reviews: MMBR 80:1-43

Bligh EG, Dyer WJ (1959) A rapid method of total lipid extraction and purification. Canadian Journal of Biochemistry and Physiology 37: 911-917

Bloem J, Hopkins DW, Benedetti A (2008) Microbiological methods for assessing soil quality. CABI Publishing, Wallingford

Bossio DA, Scow KM (1998) Impacts of carbon and flooding on soil microbial communities: phospholipid fatty acid profiles and substrate utilization patterns. Microbial Ecology 35:265-278

Bossio DA, Girvan MS, Verchot L, Bullimore J, Borelli T, Albrecht A, Scow KM, Ball AS, Pretty JN, Osborn AM (2005) Soil microbial community response to land use change in an agricultural landscape of Western Kenya. Microbial Ecology 49:50-62

Bossuyt H, Denef K, Six J, Frey SD, Merckx R, Paustian K (2001) Influence of microbial populations and residue quality on aggregate stability. Applied Soil Ecology 16:195-208 
Brearley FQ (2012) Ectomycorrhizal associations of the Dipterocarpaceae. Biotropica 44:637-648

Bruhl CA, Eltz T (2010) Fuelling the biodiversity crisis: species loss of ground-dwelling forest ants in oil palm plantations in Sabah, Malaysia (Borneo). Biodiversity and Conservation 19:519-529

Charousová I, Medo J, Halenárová E, Javoreková S (2017) Antimicrobial and enzymatic activity of actinomycetes isolated from soils of coastal islands. Journal of Advanced Pharmaceutical Technology \& Research 8:46-51

Chung AYC, Eggleton P, Speight MR, Hammond PM, Chey VK (2000) The diversity of beetle assemblages in different habitat types in Sabah, Malaysia. Bulletin Entomological Research. 90:475-496

Cooper HV, Vane CH, Evers S, Aplin P, Girkin NT, Sjögersten S (2019) From peat swamp forest to oil palm plantations: the stability of tropical peatland carbon. Geoderma 342:109-117

Coyne M s (1999) Soil microbiology: an exploratory approach. Delmar publishers, New York

Cusack J (2011) Characterising small mammal responses to tropical forest loss and degradation in northern Borneo using capture-markrecapture methods. Master of Science, Imperial College London, London

Dedysh SN, Pankratov TA, Belova SE, Kulichevskaya IS, Liesack W (2006) Phylogenetic analysis and in situ identification of Bacteria community composition in an acidic Sphagnum peat bog. Applied and Environmental Microbiology 72:2110-2117

Dhandapani S, Ritz K, Evers S, Sjögersten S (2019a) Environmental impacts as affected by different oil palm cropping systems in tropical peatlands. Agriculture, Ecosystems \& Environment 276:8-20

Dhandapani S, Ritz K, Evers S, Yule CM, Sjögersten S (2019b) Are secondary forests second-rate? Comparing peatland greenhouse gas emissions, chemical and microbial community properties between primary and secondary forests in peninsular Malaysia. Science of the Total Environment 655:220-231

Dhandapani S, Ritz K, Evers S, Sjögersten S (2019c) GHG emission under different cropping systems in some Histosols of Malaysia. Geoderma Regional 18:e0229

Dowhan W, Bogdanov M, Mileykovskaya E (2016) Chapter 1 - functional roles of lipids in membranes A2 - Ridgway, Neale D. In: McLeod RS (ed) Biochemistry of lipids, lipoproteins and membranes, 6th edn. Elsevier, Boston, pp 1-40

Fierer N, Strickland MS, Liptzin D, Bradford MA, Cleveland CC (2009) Global patterns in belowground communities. Ecology Letters 12: $1238-1249$

Frostegard A, Tunlid A, Baath E (1991) Microbial biomass measured as total lipid phosphate in soils of different organic content. Journal of Microbiological Methods 14:151-163

Frostegard A, Tunlid A, Baath E (2011) Use and misuse of PLFA measurements in soils. Soil Biology \& Biochemistry 43:1621-1625

Galand PE, Saarnio S, Fritze H, Yrjala K (2002) Depth related diversity of methanogen Archaea in Finnish oligotrophic fen. FEMS Microbiology Ecology 42:441-449

Gattinger A, Gunther A, Schloter M, Munich JC (2003) Characterisation of Archaea in soils by polar lipid analysis. Acta Biotechnologica 23: 21-28

Gilbert D, Amblard C, Bourdier G, Francez AJ (1998) The microbial loop at the surface of a peatland: structure, function, and impact of nutrient input. Microbial Ecology 35:83-93

Gillespie GR, Ahmad E, Elahan B, Evans A, Ancrenaz M, Goossens B, Scroggie MP (2012) Conservation of amphibians in Borneo: relative value of secondary tropical forest and non-forest habitats. Biological Conservation 152:136-144

Hadi A, Haridi M, Inubushi K, Purnomo E, Razie F, Tsuruta H (2001) Effects of land-use change in tropical peat soil on the microbial population and emission of greenhouse gases. Microbes and Environments 16:79-86
Hapsari KA, Biagioni S, Jennerjahn TC, Reimer PM, Saad A, Achnopha Y, Sabiham S, Behling H (2017) Environmental dynamics and carbon accumulation rate of a tropical peatland in Central Sumatra, Indonesia. Quaternary Science Reviews 169:173-187

Hartman WH, Richardson CJ, Vilgalys R, Bruland GL (2008) Environmental and anthropogenic controls over bacterial communities in wetland soils. Proceedings of the National Academy of Sciences of the United States of America 105:17842-17847

Hashidoko Y, Takakai F, Toma Y, Darung U, Melling L, Tahara S, Hatano R (2008) Emergence and behaviors of acid-tolerant Janthinobacterium sp that evolves $\mathrm{N} 2 \mathrm{O}$ from deforested tropical peatland. Soil Biology \& Biochemistry 40:116-125

Jackson CR, Liew KC, Yule CM (2009) Structural and functional changes with depth in microbial communities in a tropical Malaysian peat swamp Forest. Microbial Ecology 57:402-412

Kaiser C, Frank A, Wild B, Koranda M, Richter A (2010) Negligible contribution from roots to soil-borne phospholipid fatty acid fungal biomarkers 18:2 omega 6,9 and 18:1 omega 9. Soil Biology \& Biochemistry 42:1650-1652

Kaur A, Chaudhary A, Kaur A, Choudhary R, Kaushik R (2005) Phospholipid fatty acid- a bioindicator of environment monitoring and assessment in soil ecosystem. Current Science 89

Kerfahi D, Tripathi BM, Lee J, Edwards DP, Adams JM (2014) The impact of selective-logging and forest clearance for oil palm on fungal communities in Borneo. PLoS One 9:8

Kieft TL, Ringelberg DB, White DC (1994) Changes in ester-linked phospholipid fatty-acid profiles of subsurface bacteria during starvation and desiccation in a porous-medium. Applied and Environmental Microbiology 60:3292-3299

Krashevska V, Klarner B, Widyastuti R, Maraun M, Scheu S (2015) Impact of tropical lowland rainforest conversion into rubber and oil palm plantations on soil microbial communities. Biology and Fertility of Soils 51:697-705

Kuehn KA, Lemke MJ, Suberkropp K, Wetzel RG (2000) Microbial biomass and production associated with decaying leaf litter of the emergent macrophyte Juncus effusus. Limnology and Oceanography 45:862-870

Lee SS, Thi BK, Patahayah M (2010) An ectomycorrhizal thelephoroid fungus of Malaysian dipterocarp seedlings. Journal of Tropical Forest Science 22:355-363

Lin XJ, Tfaily MM, Steinweg M, Chanton P, Esson K, Yang ZK, Chanton JP, Cooper W, Schadt CW, Kostka JE (2014) Microbial community stratification linked to utilization of carbohydrates and phosphorus limitation in a boreal peatland at Marcell experimental Forest, Minnesota, USA. Applied and Environmental Microbiology 80:3518-3530

Liu L, Gundersen P, Zhang W, Zhang T, Chen H, Mo JM (2015) Effects of nitrogen and phosphorus additions on soil microbial biomass and community structure in two reforested tropical forests. Scientific Reports 5:10

Lucey JM, Hill JK (2012) Spillover of insects from rain Forest into adjacent oil palm plantations. Biotropica 44:368-377

Luskin MS, Potts MD (2011) Microclimate and habitat heterogeneity through the oil palm lifecycle. Basic and Applied Ecology 12: $540-551$

Miettinen J, Hooijer A, Tollenaar D, Malins C, Vernimmen R, Shi C, Liew SC (2012) Historical analysis and projection of oil palm plantation expansion on Peatland in Southeast Asia. International Council on Clean Transportation, Washington DC

Miettinen J, Shi CH, Liew SC (2016) Land cover distribution in the peatlands of peninsular Malaysia, Sumatra and Borneo in 2015 with changes since 1990. Global Ecology and Conservation 6:67-78

Mishra S, Lee WA, Hooijer A, Reuben S, Sudiana IM, Idris A, Swarup S (2014) Microbial and metabolic profiling reveal strong influence of water table and land-use patterns on classification of degraded tropical peatlands. Biogeosciences 11:1727-1741 
Moore-Kucera J, Dick RP (2008) PLFA profiling of microbial community structure and seasonal shifts in soils of a Douglas-fir chronosequence. Microbial Ecology 55:500-511

Morales SE, Mouser PJ, Ward N, Hudman SP, Gotelli NJ, Ross DS, Lewis TA (2006) Comparison of bacterial communities in New England Sphagnum bogs using terminal restriction fragment length polymorphism (T-RFLP). Microbial Ecology 52:34-44

Morris PJ, Waddington JM, Benscoter BW, Turetsky MR (2011) Conceptual frameworks in peatland ecohydrology: looking beyond the two-layered (acrotelm-catotelm) model. Ecohydrology 4:1-11

Newell SY, Morna MA, Wick R, H. R.E. (1995) Productivities of microbial decomposer during early stages of decomposition of leaves of a freshwater sedge. Freshwater Biology 34:135-148

Page SE, Hooijer A (2016) In the line of fire: the peatlands of Southeast Asia. Philosophical Transactions of the Royal Society, B: Biological Sciences 371:20150176

Parish F, Sirin A, Charman D, Joosten H, MInayeva T, Silvius M, Stringer L (2008) Assessment on peatlands, biodiversity and climate change. Global Environment Centre and Wetlands International, Selangor

Peh KSH, Sodhi NS, de Jong J, Sekercioglu CH, Yap CAM, Lim SLH (2006) Conservation value of degraded habitats for forest birds in southern peninsular Malaysia. Diversity and Distributions 12:572581

Rahman A, Sitepu IR, Tang SY, Hashidoko Y (2010) Salkowski's reagent test as a primary screening index for functionalities of rhizobacteria isolated from wild dipterocarp saplings growing naturally on medium-strongly acidic tropical peat soil. Bioscience Biotechnology and Biochemistry 74:2202-2208

Rashid, A. H. A. M., K. A. Hamzah and K. T. Joseph. 2013. Land use change in Malaysia. Reports from the technical panels of the 2nd green house gas. Roundtable on sustainable palm oil

Saiful I, Latiff A (2014) Effects of selective logging on tree species composition, richness and diversity in a hill dipterocarp forest in Malaysia. Journal of Tropical Forest Science 26:188-202

Sjögersten S, Cheesman AW, Lopez O, Turner BL (2011) Biogeochemical processes along a nutrient gradient in a tropical ombrotrophic peatland. Biogeochemistry 104:147-163

Smith AP, Marin-Spiotta E, de Graaff MA, Balser TC (2014) Microbial community structure varies across soil organic matter aggregate pools during tropical land cover change. Soil Biology \& Biochemistry 77:292-303

Sundh I, Nilsson M, Borga P (1997) Variation in microbial community structure in two boreal peatlands as determined by analysis of phospholipid fatty acid profiles. Applied and Environmental Microbiology 63:1476-1482

Thormann MN, Currah RS, Bayley SE (2004) Patterns of distribution of microfungi in decomposing bog and fen plants. Canadian Journal of Botany-Revue Canadienne De Botanique 82:710-720

Tonks AJ, Aplin P, Beriro DJ, Cooper H, Evers S, Vane CH, Sjogersten S (2017) Impacts of conversion of tropical peat swamp forest to oil palm plantation on peat organic chemistry, physical properties and carbon stocks. Geoderma 289:36-45

Too CC, Keller A, Sickel W, Lee SM, Yule CM (2018) Microbial community structure in a Malaysian tropical peat swamp forest: the influence of tree species and depth. Frontiers in Microbiology 9

Trinder CJ, Johnson D, Artz RRE (2008) Interactions among fungal community structure, litter decomposition and depth of water table in a cutover peatland. FEMS Microbiology Ecology 64:433-448

Trinder CJ, Johnson D, Artz RRE (2009) Litter type, but not plant cover, regulates initial litter decomposition and fungal community structure in a recolonising cutover peatland. Soil Biology and Biochemistry 41:651-655
Tripathi BM, Kim M, Singh D, Lee-Cruz L, Lai-Hoe A, Ainuddin AN, Go R, Rahim RA, Husni MHA, Chun J, Adams JM (2012) Tropical soil bacterial communities in Malaysia: $\mathrm{pH}$ dominates in the equatorial tropics Too. Microbial Ecology 64:474-484

Troxler TG, Ikenaga M, Scinto L, Boyer JN, Condit R, Perez R, Gann GD, Childers DL (2012) Patterns of soil Bacteria and canopy community structure related to tropical Peatland development. Wetlands 32:769-782

Turetsky MR, Benscoter B, Page S, Rein G, van der Werf GR, Watts A (2015) Global vulnerability of peatlands to fire and carbon loss. Nature Geoscience 8:11-14

Turner EC, Foster WA (2009) The impact of forest conversion to oil palm on arthropod abundance and biomass in Sabah, Malaysia. Journal of Tropical Ecology 25:23-30

Turner EC, Snaddon JL, Fayle TM, Foster WA (2008) Oil palm research in context: identifying the need for biodiversity assessment. PLoS One 3:4

Valenzuela EI, Prieto-Davo A, Lopez-Lozano NE, Hernandez-Eligio A, Vega-Alvarado L, Juarez K, Garcia-Gonzalez AS, Lopez MG, Cervantes FJ (2017) Anaerobic methane oxidation driven by microbial reduction of natural organic matter in a tropical wetland. Applied and Environmental Microbiology 83:15

Varkkey H (2013) Patronage politics, plantation fires and transboundary haze. Environmental Hazards 12:200-217

Varkkey H (2016) The haze problem in Southeast Asia: palm oil and patronage. Routledge, Abingdon

Vestal JR, White DC (1989) Lipid analysis in microbial ecology - quantitative approaches to the study of microbial communities. BioScience 39:535-541

Voglmayr H, Yule CM (2006) Polyancora globosa gen. Sp. nov., an aeroaquatic fungus from Malaysian peat swamp forests. Mycological Research 110:1242-1252

Wilkinson SC, Anderson JM, Scardelis SP, Tisiafouli M, Taylor A, Wolters V (2002) PLFA profiles of microbial communities in decomposing conifer litters subject to moisture stress. Soil Biology \& Biochemistry 34:189-200

Willers C, van Rensburg PJJ, Claassens S (2015) Phospholipid fatty acid profiling of microbial communities-a review of interpretations and recent applications. Journal of Applied Microbiology 119:12071218

Winsborough C, Basiliko N (2010) Fungal and bacterial activity in northern Peatlands. Geomicrobiology Journal 27:315-320

Wood SA, Gilbert JA, Leff JW, Fierer N, D'Angelo H, Bateman C, Gedallovich SM, Gillikin CM, Gradoville MR, Mansor P, Massmann A, Yang N, Turner BL, Brearley FQ, McGuire KL (2017) Consequences of tropical forest conversion to oil palm on soil bacterial community and network structure. Soil Biology \& Biochemistry 112:258-268

Yule CM (2010) Loss of biodiversity and ecosystem functioning in indoMalayan peat swamp forests. Biodiversity and Conservation 19: 393-409

Yule CM, Gomez LN (2009) Leaf litter decomposition in a tropical peat swamp forest in peninsular Malaysia. Wetlands Ecology and Management 17:231-241

Zelles L, Bai QY, Beck T, Beese F (1992) Signature fatty-acids in phospholipids and lipopolysaccharides as indicators of microbial biomass and community structure in agricultural soils. Soil Biology \& Biochemistry 24:317-323

Publisher's Note Springer Nature remains neutral with regard to jurisdictional claims in published maps and institutional affiliations. 